\title{
ResearchOnline@JCU
}

This is the Accepted Version of a paper published in the journal: Global Environmental Change

Hettiarachchi, Missaka, Morrison, T.H., and McAlpine, Clive (2015) Forty-three years of Ramsar and urban wetlands. Global Environmental Change, 32. pp. 57-66.

http://dx.doi.org/10.1016/j.gloenvcha.2015.02.009

(C) 2015. This manuscript version is made available under the CC-BY-NC-ND 4.0 license

http://creativecommons.org/licenses/by-nc-nd/4.0/

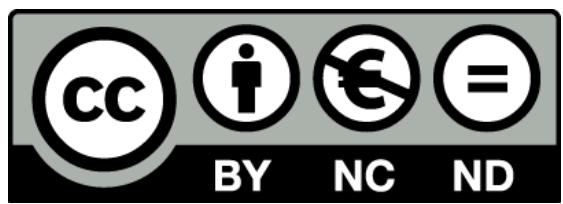




\title{
Forty-three Years of Ramsar and Urban Wetlands
}

By M. Hettiarachchi, T.H. Morrison \& C. McAlpine

Published in Global Environmental Change (2015), Vol 32, pp. 57-66.

Please note that this publication is provided under Green Open Access. The publication is not Gold Open Access due to the publisher's copyright restrictions.

Citation: Hettiarachchi, M., Morrison, T. H., \& McAlpine, C. (2015). Forty-three years of Ramsar and urban wetlands. Global Environmental Change, 32, 57-66.

\section{FORTY-THREE YEARS OF RAMSAR AND URBAN WETLANDS.}

\begin{abstract}
The Ramsar Convention is unquestionably the backbone of modern wetland management theory and practice. In the last four decades, it has mainstreamed wetlands in the environmental discourse and fostered the development of a comprehensive institutional framework for wetland governance. However, many of the wetlands that occur in human-dominated landscapes remain acutely threatened. The problem is most alarming in urban areas, especially in the fast expanding cities of the developing world, where unprecedented wetland destruction is leading to recurring environmental disasters. This triggers the question: are these failures in wetland governance purely induced by factors exogenous to Ramsar-based institutions or are they manifestations of conceptual drawbacks within the Ramsar conceptual framework? Here, we investigate the success and failures of the application of the Ramsar framework's policy directives and management guidelines for urban wetlands using two rapidly expanding cities in South Asia as case studies Colombo (Sri Lanka) and Kolkata (India). We conclude that despite its remarkable achievements over the past four decades, the Ramsar framework has several conceptual drawbacks that weaken its effectiveness in complex urban contexts. An inadequate recognition of the complex dynamics of urban social-ecological systems, an inadequate recognition of the political complexity of policy processes, and a lack of an environmental justice perspective are the main shortcomings contributing to failures in urban wetlands governance. While we acknowledge that some solutions are contingent upon national socio-political processes and reforms, we offer a pragmatic set of technical and strategic modifications to the Ramsar framework that can significantly improve its effectiveness in urban wetlands governance.
\end{abstract}

Keywords: emerging cities, Ramsar Convention, urban socio-ecological systems, justice, environmental governance 


\section{Introduction}

'The Convention on Wetlands of International Importance' (commonly known as the Ramsar Convention, 1971) is generally understood to be the pioneer global agreement on nature conservation (Matthews 1993). Ramsar established the first globally coordinated institutional framework for conservation of a threatened ecosystem type, and set the standard for the major global conservation treaties that followed, such as the Convention on Migratory Species (1983) and the Convention on Biological Diversity (1993). However, despite Ramsar's remarkable achievements, the threats to the health and survival of many of the world's wetlands have not diminished since 1971. Both sceptics and optimists agree that the majority of wetlands in human-dominated landscapes continue to be threatened regardless of their protection status (Bowman 2002, Adaman et al. 2009, Seto \& Fragkias 2007). In particular, urban wetlands have been most neglected.

Reports from post-industrial countries such as the U.S.A. and Japan have offered evidence of substantial loss and environmental degradation of urban wetlands in the past century (Mushacke \& Picard 1999, Natori 1993). In the rapidly expanding 'emerging cities' of the developing world, there has been an acceleration of wetland loss, degradation and related environmental disasters in the past three decades (Hettiarachchi et al. 2012; Xu et al. 2009; Ghosh \& Sen 1987). Indeed urban wetlands were not formally recognized as a concern in the Ramsar discourse until 2008 (Res X.27). The continuing degradation of urban wetlands in concert with the delayed recognition of the importance of urban wetlands by the Convention therefore poses a critical question: are there specific shortcomings in the 'Ramsar framework' that preclude the successful development of strategies and technologies to manage the rapid and complex transformation of urban wetlands? Here, we analyse the entire collection of convention texts, resolutions, recommendations, and technical guidelines under the 'Ramsar framework' with this question in mind.

The study of urban ecology is underpinned by the premise that ecological processes and interactions among ecological and social elements in an urban ecosystem are fundamentally different to that of non-urban environments (Pickett et al. 2008). This difference is not so much about the non-pristine nature of urban environments (the notion of pristine being widely contested in political ecology and nature-society geography literature), but about the 
"interwoven knots of social process, material metabolism and spatial form that go into the formation of contemporary urban socio-natural landscapes" (Swyngedouw and Heynen 2003, 906, also see Robbins 2012; Zimmerer 2000). Urban-specific components and the idiosyncratic interactions among these components in urban ecosystems call for specialized modes of investigation and governance. It is also important to acknowledge here that most compounding urban environmental issues today are consistent products of the current global political-economic order rather than avoidable anomalies (Ernstson 2013; Schmidt and Morrison 2012; Keil 2003).

These arguments have been empirically confirmed in recent urban wetlands research (Hettiarachchi et al. 2013; Ehrenfeld 2004; Azous \& Horner 2001). Urban wetlands are threatened by alarming levels of degradation and loss in both developing (emerging) and post-industrial cities. For example, real estate development has caused acute $(>50 \%)$ conversion rates of New York's (U.S.A.) tidal wetlands (Mushacke \& Picard 1999) despite a conservation program in place under the New York Tidal Wetlands Act (1973) (Natural Resources Defence Council 1990). Recent research has also demonstrated that the way wetlands are understood, evaluated and valued by the urban communities are different to that of rural or agricultural wetlands (Nassauer 2004, Ehrenfeld 2000, Mahan et al. 2000). Wetland degradation is more complex in 'emerging cities' where social inequalities and poor planning magnify the environmental pressures of economic expansion (Dasgupta 2007). While failures in urban wetland governance cannot be fully mitigated by the current Ramsar guidelines and policy directives, it remains critically important to identify the relevant limitations in the Ramsar framework itself and formulate strategies to overcome them. It is imperative therefore that we develop 'urban-specific' environmental management tools, strategies, and institutions for effective urban wetland governance.

This article investigates the application of the current Ramsar framework to urban wetlands governance, focusing on emerging cities in developing countries. We investigate the main conceptual strengths and weakness of the Ramsar Framework with regard to urban wetland governance in rapidly expanding developing country cities and analyse the root causes of weaknesses through the lenses of environmental policy and governance theory (Bulkeley and Betsill 2013; Morrison 2007), community participation frameworks (Robinson \& Berkes 2011), and environmental justice theory (Pulido 2000). We focus on two South Asian cities (Colombo, Sri Lanka and Kolkata, India) as case studies. First, we examine the historical 
development of the Ramsar Convention and map its conceptual ramifications. Second, we present the current institutional arrangements of the two selected cases and investigate their compatibility with the Ramsar framework. Next, we present policy and management outcomes for the two cases and critically analyse how the inherent conceptual limitations in the Ramsar framework have contributed to both positive and negative outcomes. Based on the lessons drawn from the cases, we suggest strategic and technical modifications to the Ramsar framework to strengthen its applicability in urban wetland governance, particularly in the emerging cities. Finally, we discuss the social and political processes that are beyond the institutional scope of the Ramsar framework, yet which are critically important in ensuring the survival of wetlands in emerging cities.

The data present in the case analysis (2009-2012) were obtained through archival research of government legislation, regulations and internal agency reports, 37 key informant interviews, field observation (management focus groups and community focus groups) and participantobservation (government meetings and co-operative meetings) in Colombo and Kolkata. Two participatory research workshops were organized in Colombo (September 2011) and Kolkata (October 2012). We therefore collected both quantitative and qualitative data on the social, ecological, and institutional aspects of urban wetlands governance in these cities. Although most governance procedures and institutional links were well documented in both cases, we sought triangulation through multiple methods, such as expert interviews, participant observation and structured interviews. The ecological outcomes of the policies were obtained from existing scientific literature and verified through field observation. The entire Ramsar framework (Convention text, resolutions, recommendations, technical documents, and scholarly articles) was then interrogated against this data.

\section{The Ramsar Framework}

International environmental treaties are legal institutions that bind multiple nations to a given environmental objective. The Ramsar Convention (1971) is one of the oldest among such global treaties and was the first to focus on the conservation of a particular ecosystem type. It subsequently heralded a series of conservation-oriented global treaties such as the World Heritage Convention (1972) and the Convention on Migratory Species (1979). 
The development of Ramsar was the result of a lengthy process undertaken to attain a universal consensus and to establish an overarching legal framework to protect waterfowl habitat globally (Matthews 1996) and had a quintessential conservation orientation. Indeed, it was spearheaded by non-government conservation organizations (see Figure 1 for organizational structure). The signing of the Convention was significantly delayed by political disagreements among the national signatories, especially the major players in the Cold War in Europe (Matthews 1996). Partly to ensure neutrality and also due to funding constraints, the International Union for Conservation of Nature (IUCN) was asked to host the office of the Convention. This historical foundation ingrained two characteristics in the conceptual development of the Convention. First, a protected-area-based conservation approach was of central importance. Second, an immutable deference to "national sovereignty' was etched into the vision of the Convention.

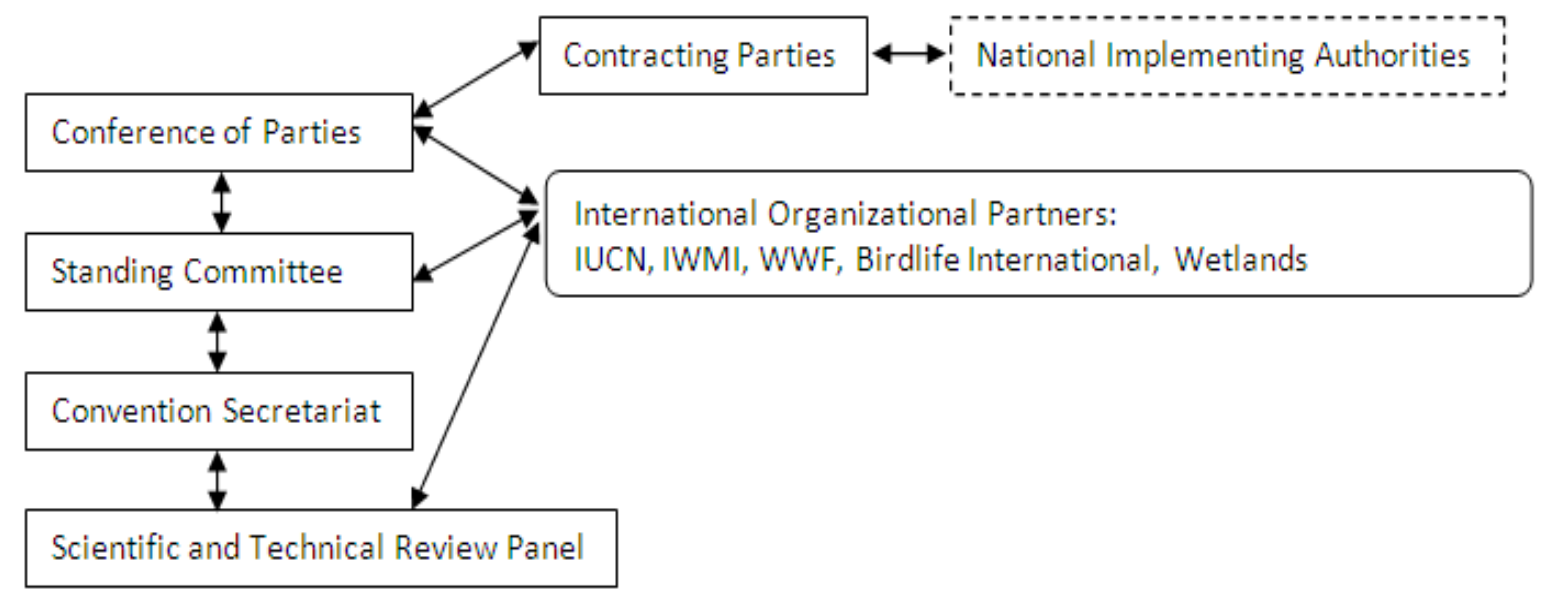

Figure 1: The current organizational framework of the Ramsar framework. The Contracting Parties (member states) and the International Organizational Partners constitute the body of members. The Conference of Parties $(\mathrm{CoP})$ is the ultimate decision-making forum that convenes every three years. The other three bodies have representative, technical, or administrative staff accountable to the CoP. The National Implementing Authorities (in dashed box) represent the Convention at the national level.

The Ramsar framework was built on three conceptual pillars: 1) Ramsar site designation and management; 2) wise use of wetlands; and 3) international cooperation. Despite its conservation-oriented beginnings in 1971, the Convention underwent some significant reiterations. The most relevant conceptual developments (1971-2014) to our analysis are described below. 


\section{Wetland site designation and management (1970s)}

The initial focus of the Ramsar framework was on designating 'internationally important wetlands' in the territories of signatory Parties, offering them 'protected-area' status under national laws (Article 2.4 of the Convention text). The convention demanded the maintenance of the particular ecological state ('ecological character' in Ramsar terminology) that was identified at the time of designation. To achieve this, inventorying, monitoring, and impact assessments of wetlands became important activities, and comprehensive guidelines regarding these areas, were developed.

Wise use and the drive for national policy reform (1980s)

The Convention's preoccupation with waterfowl conservation was dropped by the early 1980s and a new emphasis on 'wise use of wetlands' (Article 3.2) gradually gained strength. This conceptual development was largely influenced by the World Conservation Strategy (1980) and the growing international discourse on environment and development (Matthews 1996). The 'wise use' theme gained momentum as more developing countries entered the convention (Bowman 2002). The term 'wise use' is very broadly defined as the 'sustainable utilization of wetlands for the benefit of humankind in a way compatible with the maintenance of the natural properties of the ecosystem'. However, the Parties to the Convention could and did adopt rather more fluid definitions. Towards the late 1980s, the Convention's focus extended beyond the 'designated wetlands' to all wetlands in the territory of a Party. However, within the Convention, the nations were represented by politically less powerful environmental or conservation agencies (national implementing authorities) that did not necessarily have a mandate over all land management and land-use planning.

Ramsar therefore encouraged the Parties to formulate national-level wetland policies and carry out policy reviews in order to eliminate legal and institutional barriers for wetland protection (e.g. Ramsar Resolution VII.6 and VII.7 of 1999). Adopting national wetland policies gained remarkable traction towards late 1990s, although the practical implementation of some of these policy statements has been very slow (Hettiarachchi et al. 2012; Adaman et al. 2009; Bowman 2002).

\section{Ecosystem services, human well-being and wetland valuation (1990s and 2000s)}

From the late 1990s, the concept of 'ecosystem services' gained prominence in the Ramsar discourse. The Convention was a key partner to the Millennium Ecosystem Assessment 
project (2001-2005) and officially adopted the project's recommendations through Resolution X.3 (the Chowgon Declaration) and Resolution X.18 made in 2008. The importance of the evaluation and protection of ecosystem services provided by wetlands and associated implications for human well-being became a central premise of the 2009-2015 Strategic Plan of the Convention. The Convention also identified that wetlands have multiple values - social, cultural, and economic. It developed guidelines on both economic (Barbier et al. 1997) and cultural (Papayannis 2008) values and valuation methods, although there was a notably stronger emphasis throughout on economic valuation.

Participation, awareness, and partnerships (2000s)

Another concept that gained significant traction within the Ramsar discourse was 'stakeholder/community involvement' in wetlands management. This included participation of local and indigenous communities, environmental awareness-building and public-private partnerships. This was in line with the general tendency towards participatory approaches in the conservation community (especially within the IUCN), and it was accelerated by the Convention's shift towards 'ecosystem services' based management. The 2009-2015 Ramsar Strategic Plan emphatically laid out the importance of community participation and partnerships guided by Resolutions VII.8 and X.8. However, it should be noted that most of the participation tools recommended in Ramsar guidelines are restricted to basic levels of local community participation rather than full empowerment.

\section{Ramsar and urban wetlands - recent developments}

The Convention's first official acknowledgment of the importance of urban wetlands was Resolution X.27 (2008), a spin-off of the Curitiba Declaration on Cities and Biodiversity (2007). A more comprehensive declaration on urban wetlands was made in 2012 by the Resolution XI.11. The resolution adopted four overarching principles of urban wetland governance (Figure 2), and stated five practical principles to guide management: 1) wetland conservation; 2) wetland restoration and creation; 3) understanding the value of wetlands; 4) stakeholder engagement; and 5) integrated planning. 


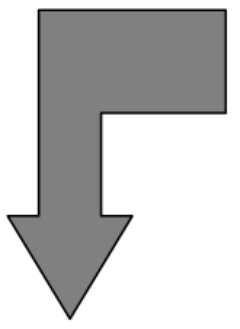

\section{Overarching Principles}

No further degradation of wetlands as a result of urban development.

Wetlands should be considered as essential water management infrastructure.

Wetlands should be restored and created as elements of urban infrastructure in order to optimize ecosystem service delivery.

The wise use of wetland should be considered as a key component within sustainable human settlements.

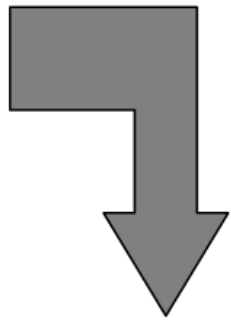

\section{Urban development guidance}

How to inform existing networks, associations and organizations.

How to raise awareness, deliver successful information exchange and capacity build.

How to develop examples of sustainable urban and wetland management.

Case studies

\section{Urban development guidance}

Illustrative guidance on the protections and conservation of existing wetlands within the context of urban development.

Illustrative guidance on the utility of wetlands as essential water management infrastructure within urban settlements.

Case studies.

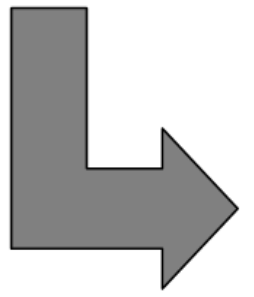

\section{Target audience}

Overarching principles aimed at national governments.

Guidance aimed at local government

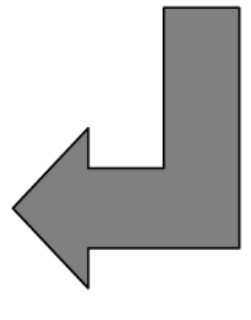

Figure 2: Schematic of the relationship between the overarching principles of urban wetlands management adopted by Resolution XI.11 and the proposed development of practical guidance for different target audiences (Source: Ramsar Resolution XI.11). 
In summary, the Ramsar Convention has undergone significant conceptual transformations since its inception in 1971. The initial narrow, protectionist views have been superseded by the principles of 'wise use', maintaining and restoring ecosystem services, and community participation, all of which have had a crucial and positive impact on wetland management theory and practice. However, the Convention's application in many specific areas, such as urban wetlands, remains in need of further assessment. Next, we evaluate the main strengths and weakness of the Ramsar Conceptual Framework with regard to urban wetland governance in South Asia from an institutional and socio-ecological perspective.

Recent developments in environmental governance and urban ecology scholarship highlight that understanding complex eco-social dynamics, convoluted policy processes, and social equity concerns are imperative in effective environmental management. The importance of holistically analysing the complex eco-social systems have been highlighted in many different strands of environmental scholarship such as urban ecology (Picket et al. 2008), political ecology (Robbins 2012), and adaptive systems theory (Levin 1998). Modern policy studies acknowledge that the traditional 'positivist' approach of scientific policy making is rarely achieved in the real world of environmental and natural resources governance (Bulkeley \& Betsill 2013, Urwin \& Jordan 2008, Morrison 2007) and that there is a need to interrogate actual political bargaining processes, multiple scales of governance, and opposing policy actors. Within such complex eco-social and political contexts, formal provisions for community participation alone will not guarantee social equity in environmental governance. Therefore, environmental justice scholars argue that access to natural resources and ecosystem services should be established as a civic right (Pulido 2000; Cutter 1995). This perspective also acknowledges the difference between nominal consultation, and multi-level community participation and empowerment (Robinson \& Berkes 2011, Arnstein 1969), and the need for constant revision and adaptation through social learning and policy learning (Pahl-Wostl 2009, Keen et al. 2005; Irvin \& Stansbury 2004) to ensure social equity in solving intransigent environmental problems. We use these perspectives to analyze how the conceptual foundation of the current Ramsar framework practically manifests in urban wetland governance. We do this through a comparative case analysis of urban wetland governance in Colombo and Kolkata. 


\section{Case Results and Analysis: Urban Wetlands Governance in Colombo and Kolkata}

Historically, wetland loss in developing countries has been significant yet lower than in postindustrial countries. In 1985, the cumulative losses of coastal and inland marshes in highly populated areas of Europe and North-America was 65-65\%, whereas in Asia it was 27\% (Smardon 2009). However, the projected losses are now the highest in the developing world, particularly in Asia, where the urban population is predicted to increase by 1.4 billion by 2050 (UN 2011) making the urban wetlands acutely threatened. In the past two decades, wetland loss, degradation and related social impacts such as urban floods and livelihood loss have risen alarmingly in most South and Southeast Asian cities (Smardon 2009, Azarath et al. 1988, Ghosh \& Sen, 1987). Urbanization patterns and development policy trends in these emerging cities are significantly different from the growth trajectories of post-industrial cities (Marcuse \& Kempen, 2000). We selected two South Asian case studies, Colombo (Sri Lanka) and Kolkata (India), to closely investigate urban wetland governance in emerging cities in developing countries. Both cities have grown rapidly with the economic globalization of South Asia. The wetlands of Colombo and Kolkata had been in community use well before the establishment of the cities under colonial rule. The governance histories of both wetlands are well documented and comparable due to common administrative traditions of South Asia. However, they also deviate in many characteristics. Kolkata is the $10^{\text {th }}$ largest urban agglomerate of the world (population - 14.1 million) and has a strong democratic tradition of governance, whereas Colombo is a much smaller city (population 1.3 million) with a history of more authoritarian rule. Both India and Sri Lanka are signatories to the Ramsar Convention and have adopted advanced national wetland management policies and strategies. The wetlands of Kolkata were designated as a Ramsar site in 2002. The Colombo wetlands, however, are not designated Ramar sites.

The city of Kolkata has a vast network (12,500 ha) of wetlands constituted by ponds, marshes, and paddyfields. Historically, these wetlands were a part of the common interdistributory marsh network of the lower Ganges delta region, hydraulically connected to the Bay of Bengal. Sewage and storm water from the city of Kolkata was channelled to the wetlands from early $20^{\text {th }}$ century onwards under British colonial rule. This threatened the ecological stability of the wetland, but gradually sewage waste was converted for use as a water and nutrient source for pisciculture and agriculture by the local fishing communities. 
Today, Kolkata has the world's largest network of wastewater remediation wetlands maintained entirely by local communities. In 2010, the wetland received $0.7-1.0$ million cubic metres per day ( $\mathrm{m}^{3} /$ day) of wastewater from Kolkata, and produced 16,000 tonnes of rice, 30,000-50,000 tonnes vegetables, and 8,000 tonnes of fish per annum.

In Colombo, a smaller network $(\sim 1,200 \mathrm{ha})$ of freshwater marshes, open waterways, and paddylands is scattered across the metropolitan area. Most of these wetlands are 0.3-0.7 metres (m) above mean sea level and become fully inundated during the monsoonal peaks (May-September). The wetlands were intensely engineered and hydrologically separated from the rest of the wetlands along the western coast of Sri Lanka by the 1928 Colombo Flood Protection Plan. These wetlands were traditionally used for rain-fed rice cultivation, animal husbandry, fishing, and canal-based transport. However, drainage and flood control were given prominence as the city expanded and the importance of all other ecosystem services waned or disappeared by the early 1980s. At present, these wetlands form the critical flood retention areas for a city that experiences severe flash floods and damage each year.

\subsection{Institutional frameworks}

Urban wetland governance in Colombo and Kolkata has evolved over more than a century of colonial, post-colonial, and neo-liberal history in South Asia. The current institutional and organizational frameworks of urban wetland governance in the two cases (derived from archival and key informant data) are shown graphically in Figure 3.

\section{Colombo}

Sri Lanka joined the Ramsar convention in 1990 and has since been a diligent follower of the Ramsar framework. A comprehensive process for wetland inventorying and siteinvestigations (funded by the Dutch government) was conducted from 1991 to 1995, and this included the Colombo wetlands (CEA 1994). A National Wetlands Committee was established in the early 1990s, and the National Wetlands Policy, which in general follows the Ramsar guideline (Resolution VII.6), was adopted in 2005. Numerous site-specific wetland management plans and overall strategic plans were formulated by the Central Environmental Authority of Sri Lanka based on Ramsar documents, including one specifically for the Colombo wetlands (CEA 1994). These plans mainly advocated the principles and strategies outlined in Table 1. 
Table 1: Prominent features (principles and strategies) of wetland policy documents in Colombo and Kolkata.

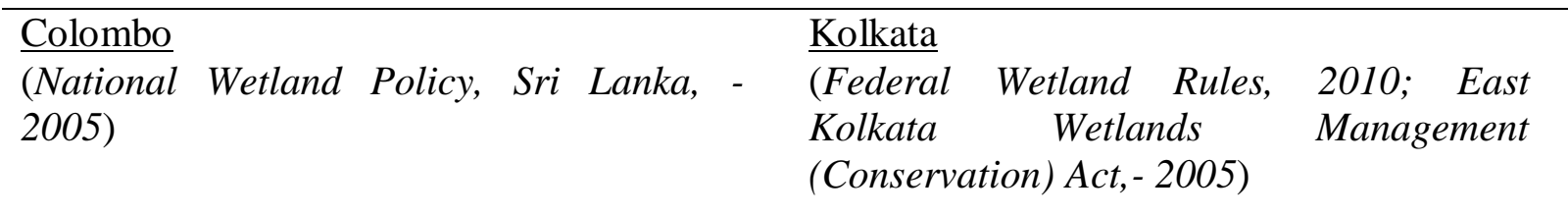

Main principles

Wetland conservation and prevention of illegal use.

Effective penalization of polluters.

Encouragement of community

participation.

Protection of wetland ecosystem services.

Economic valuation of wetlands.

Commitment to Ramsar Convention.

\section{$\underline{\text { Strategies (proposed) }}$}

Establishment of wetland management committees at site level.

Provisions for civic participation.

Coordination of land-use planning.

Wetland-friendly drainage systems.

Multidisciplinary wetland research.

Public awareness campaigns.
Main principles

Cross-sectoral policy integration.

Wetland conservation and prevention of illegal use.

Wetland delineation, demarcation, and monitoring.

Effective penalization of polluters.

Encouragement of community

participation.

Management of wetland uses (agriculture, fisheries).

Commitment to Ramsar Convention.

$\underline{\text { Strategies (implemented and proposed) }}$

Establishment of high-level coordinating bodies with regulatory powers (NWRA, EKWMA).

Wetland mapping and regular monitoring.

Review of laws and procedures.

Public awareness campaigns.

Networking with research organizations.

At the time of writing, Colombo's wetland governance came under the direct purview of five state agencies operating in urban development, environment, disaster management, and agricultural extension (Figure 3), with very little cross-sectoral communication. The responsibility of managing the hydraulics of the wetland system was with the Sri Lanka Land Reclamation and Development Authority (SLLRDC), which also had the legal titles for 540 hectares (ha) of the wetland extent. The agency's affiliation with the Ministry of Defence and 
the clear legal mandate provided by successive amendments to the Sri Lanka Land Reclamation and Development Authority Act (1968, 1982, 2006), has given it the strongest political influence within the system. The Central Environmental Authority (CEA) is the de facto guardian of wetlands in Sri Lanka; it heads the National Wetlands Committee and shared the Ramsar-implementing authority responsibilities with its sister agency, the Department of Wild Life Conservation. The Authority has also maintained some control over environmental management at municipal and shire level. However, its involvement in urban planning in Colombo is nominal. While the Authority drafted the National Wetlands Policy of Sri Lanka under the patronage of Ministry of Environment in 2005, its strategies remained largely unimplemented and neglected by the more powerful urban development agencies. Moreover, the policy had no explicit strategies to address issues specific to urban wetlands (Table 1). The authority maintained a small wetlands unit in its head office with activities focused more on awareness building than policy advocacy. The fallowed paddylands in the Colombo wetlands nominally came under the jurisdiction of the Agrarian Services Board (ASB), which has been overwhelmed by the crisis-ridden rural agriculture sector of Sri Lanka and unable to allocate any resources to manage fallowed urban paddylands in Colombo.

\section{Kolkata}

Despite its entry into the Convention in 1982, India was slow in designating sites and adopting the Ramsar framework in its wetland governance. Given the inevitable difficulties due to its geographic extent, wetland inventories were conducted only intermittently (Panini 1998). However, the Kolkata wetlands received Ramsar designation in 2002 as a result of initiatives by a few determined individuals (state-sector champions) and NGOs. The East Kolkata Wetlands Management Act (2006) was strongly influenced by the Ramsar policy guidelines. The Wetlands Management Authority established under this act was also modelled after the other Ramsar site-management bodies in India such as the Chilika Lake Development Authority. In 2010, the government of India declared national Wetland Rules to regularize further the management of all Ramsar sites following the Ramsar guidelines (Resolution VII.7). 

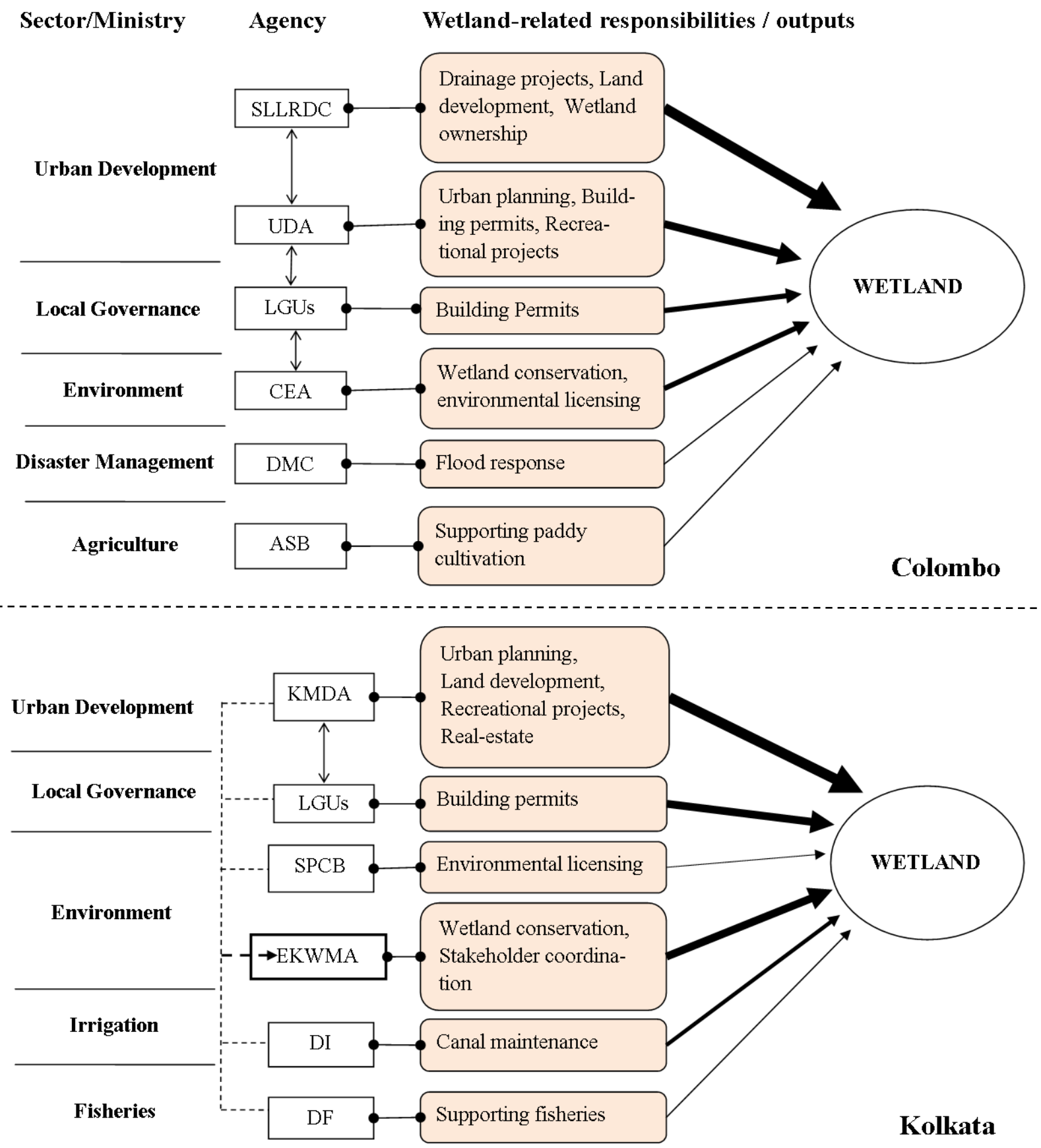

Figure 3: Organizational framework of urban wetlands governance in Colombo (A) and Kolkata (B) The key agencies are categorized according to sector/ministry and cross-sectoral links are indicated. Wetland-related responsibilities and outputs of each agency are also indicated with the magnitude of impact on the wetlands represented by the thickness of the arrows (based on archival and key informant data). SLLRDC - Sri Lanka Land Reclamation and Development Corporation; UDA-Urban Development Authority; CEA-Central Environmental Authority; LGUs_-Local Government Units; DMC - Disaster Management Centre; ASB - Agrarian Services Board; KMDA-Kolkata Metropolitan Development Authority; EKWMA-East Kolkata Wetlands Management Authority; SPCB-State Pollution Control Board; DI-Department of Irrigation; DF—Department of Fisheries. 
In Kolkata, the wetlands come under the legal mandate of five organizations operating in the urban development, environment, and fisheries sectors (Figure 3). The most striking difference in the Kolkata wetlands governance framework was the East Kolkata Wetlands Management Authority (EKWMA), which was an umbrella organization that provides crosssectoral policy integration. However, another authority - the Kolkata Metropolitan Development Authority (KMDA) -, backed by the political weight of the Ministry of Urban Development and state, federal, and corporate funding, was commonly in a position to easily circumvent or supersede the Wetlands Authority in urban planning decisions. The Wetlands Authority had no organizational base in the fishing community other than via nominal representation through the Department of Fisheries (DF) on the Board. It had partnerships with few research organizations and NGOs, and there were no strong alliances that offered the Wetlands Authority an advantage in policy advocacy in other policy sectors such as urban development. The Department of Fisheries (West Bengal) was specialized for operating in rural areas, and had neither tools nor incentives to cope with the urban-specific problems of the wastewater fishery in the East Kolkata Wetlands.

\subsection{Socio-ecological outcomes}

A summary of the socio-ecological outcomes in our two cases reveals that the urban wetlands in both have undergone tremendous ecological changes and remain ecologically threatened (Table 2). The current governance frameworks - the formal institutional arrangementsappear to be limited in their ability to eliminate or mitigate these threats.

Adverse environmental impacts on the two systems have resulted in serious negative social implications (displacement, loss of livelihood, increased disaster risk). The causes and consequences of the ecological transformation in both wetland systems are very complex. The exponential growth of the urban real-estate market in South Asia after the neo-liberal reforms in 1980s and 1990s has changed the land-use patterns in both cities irreversibly, undermining the survival of the wetlands. In Colombo, these factors have caused an overall ecological-character transformation of the wetlands and the significant decline of the wetland's flood-regulation capacity (Hettiarachchi et al. 2014a; Hettiarachchi, et al. 2014b). The poorer populations are either facing increased flood risk or being evicted from their settlements to make way for flood engineering schemes (Gunasekara 2010). In Kolkata, the wastewater fishery system is rapidly degenerating due to declining profitability, neglected 
maintenance, and inflated land prices (Ghosh 2005, Dasgupta 2007). In both cases, urban development agencies have followed an openly hostile policy towards the wetlands, with a view to reducing them to a network of premium urban real estate, engineered flood control infrastructure, and commercial recreational areas (promoted as 'eco-tourism'). However, the wastewater fishery system in Kolkata, which developed out of a combination of strong community cohesion, diverse ecosystem services, and informal institutions, has given its wetland system a better prospect of survival than the wetlands in Colombo.

Table 2: Comparison of the outcomes of urban wetland governance, and urban development policies in Colombo and Kolkata (based on key informant interviews and workshops).

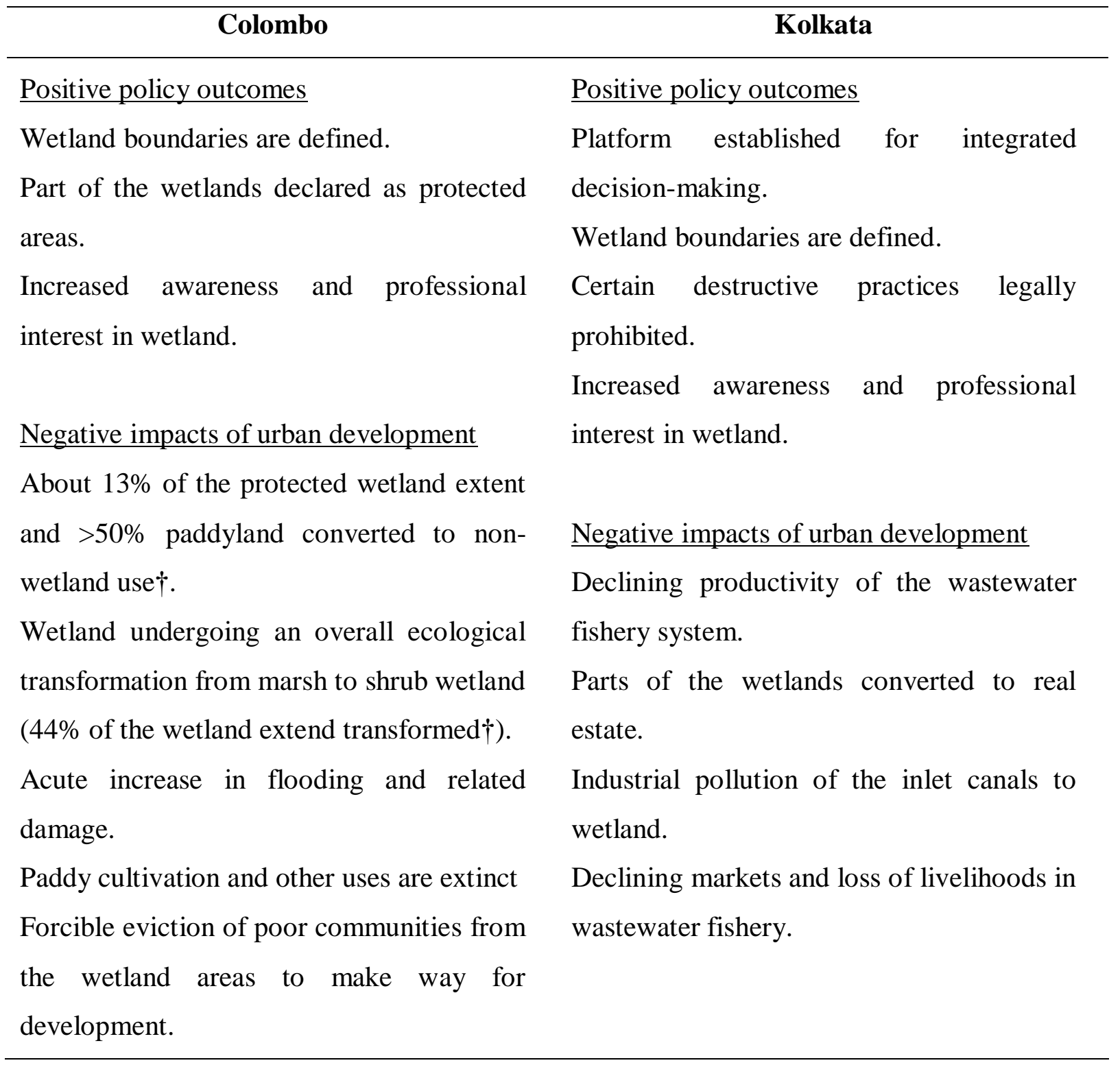

$\dagger$ source: Hettiarachchi et al. 2014 


\section{Synthesis}

\subsection{Influence of the Ramsar framework on urban wetland governance in South}

Asia

The case study results demonstrate the strong influence of Ramsar in the governance of the urban wetlands of South Asia. The exclusive wetlands governance institutions of Colombo and Kolkata were modelled based on the Ramsar guidelines. The Ramsar-based institutions have delineated the basic laws for wetlands protection in the two cities. An organizational structure has been established for both cities that focus exclusively on wetland protection. A generation of specialized wetland professionals (ecologists, engineers, administrators and lawyers) are being trained in these organizations, and these people will have a professional interest in keeping wetlands as a central focus in the environmental policy process. Therefore, the Ramsar framework has been the undisputed backbone of formal wetland protection in both cases. While acknowledging that the loss and ecological transformation of urban wetlands in Colombo and Kolkata were induced by broader political-economic causes which are far beyond the influence of the environmental policy domain in which the Ramsar-based institutions operate, we highlight below the inherent weaknesses of these institutions that have contributed to continuing urban wetland degradation.

First, the formal institutional frameworks for urban wetland governance in both cases were deeply embedded in the environment policy domain. Yet, most of the threats to the wetlands have emerged through urban development policy and cannot be mitigated by environmental policy alone. In the fast-growing cities of developing countries, where cross-sectoral policy integration is non-existent and corruption is rampant, environmental policy can be legally circumvented or neglected with impunity. Even when cross-sectoral coordination is facilitated through platforms such as the East Kolkata Wetlands Management Authority, this coordination is not truly realized due to a lack of commitment from other sectors.

Second, neither the management process nor the institutions provide adequate representation or empowerment to the most vulnerable groups in the systems, such as the fisher communities in Kolkata and the urban poor in Colombo. There is no mention of the rights of the wetland communities in the official documents related to both cases (Table 2). The notion of 'environmental justice' is absent. 
Third, there was no attempt among environmental agencies to build alliances with likeminded government agencies or to make use of existing institutional structures and community organizations for wetland protection. Particularly for Kolkata, the Wetlands Act makes no attempt to incorporate the strength of any existing, informal institutional structures of the wastewater fishery system.

Finally, in neither case were the relevant authorities equipped scientifically or practically to cope with the complex nature of ecological transformation in the wetlands. The suggested conservation strategies were only intended to handle simple unidirectional environmental pressures such as point-source pollution, direct conversion of wetlands, or introduction of invasive species. More complicated and subtle pressures such as urbanization of watersheds, hydrological modification, or non-point-source pollution continued to persist outside these protection mechanisms, even where these mechanisms were effectively implemented.

These debilitating governance failures as we observe are not only caused by poor implementation but also are a result of the inherent weaknesses of these Ramsar based institutional arrangements; which questions the effectiveness of the Ramsar framework in urban wetland governance. The specific weaknesses identified here have been broadly noted by many other researchers from different regions (Bowman 2002, Adaman et al. 2009, Seto \& Fragkias 2007). This highlights the urgent need to make important strategic and technical modifications to the Ramsar framework to overcome these weaknesses. The suggested modifications outlined below are critical to ensure improved urban wetland governance across cities of developing countries.

\subsection{Fine-tuning Ramsar for urban wetlands: technical and strategic improvements}

We observe four notable conceptual gaps in the current Ramsar framework that have contributed to failures in urban wetland governance. First, the Convention does not acknowledge the concept of complex and transforming adaptive eco-social systems as documented by modern urban ecologists, political ecologists and resilience theorists (Robbins 2012, Marzluff et al. 2008; Levin 1998). Second, Ramsar's conceptual adaptation of participatory management is little more than perfunctory and fails to cover the advanced 
participation possibilities or empowerment either conceptually or strategically. Third, the prescribed policy approach in the current Ramsar guidelines is mainly based on the principles of objective policy analysis, and underestimates the political complexity of actual public policy processes. Fourth, the Ramsar Framework also fails to acknowledge the concept of "environmental justice" as a principle. These basic conceptual deficiencies - as we have discussed - have lead to a plethora of policy and strategy weaknesses. Therefore, both in general and specific to the cases, we suggest the following technical and strategic improvements to the Ramsar framework, which we believe will significantly strengthen its effectiveness in urban wetland governance.

\section{Expansion of the science and technical guidelines to cover urban specific themes}

Currently, there is no substantial coverage within the Ramsar literature on the impacts of actions such as the fragmentation and urbanization of wetland watersheds, urban drainage, and decentralized sanitation. Neither are the critical theoretical developments on novel ecosystems (Hobbs 2009), resilience of adaptive systems (Levin 1998) and urban ecology (Marzluff et al. 2009) adequately incorporated into the scientific framework of Ramsar. Some established technologies very pertinent to urban wetlands management, such as watersensitive urban design (Water by Design 2009), also are conspicuously absent in the Ramsar literature. We recommend that the Ramsar framework expand the coverage of these themes in its literature pertinent to urban wetlands; as has been done for certain other wetland types (mangroves, peatlands). This would help establish urban wetlands as an independent area of concern in the wetland management discourse. Such material with the internationally acclaimed Ramsar logo will also become a valuable tool for articulating the importance of urban wetlands in local- or national-level urban planning.

\section{Promotion of mixed land-use planning concepts for urban planning}

The foremost landscape planning concept advocated in the Ramsar framework is 'zoning' (Recommendation 5.3); that is defining zones for desired land uses. However, most zoning attempts in emerging developing country cities have largely failed to achieve the desired environmental outcomes (Yokahari et al. 2008; Roy 2009), therefore alternative mixed landuse planning concepts need to be explored, in order to sustainably mange urban wetlands. For example, Yokahari et al. (1998, 2008) has suggested 'controlled mixture of urban-rural landscapes' as an alternative planning paradigm. They specifically advocate the maintenance of multi-purpose paddylands within certain parts of the city, a concept that is particularly 
applicable to most Asian urban wetlands. We therefore recommend that not only should the Ramsar framework adopt alternative land-use planning concepts, but also that the Convention should actively contribute to their research and development.

Emphasis on the importance of strengthening multi-scalar governance networks and individual champions

The current Ramsar guidelines strongly advocate policy integration and integrated planning. However, they fail to address the strategy of developing policy networks and strengthening the role of individual champions to overcome the disadvantages of asymmetry in political power between environmental and urban development agencies. In the real world, policy agenda-setting occurs via bargaining that goes on between rival policy actors and coalitions (Urwin and Jordan 2008, Sabatier \& Jenkins-Smith 1999) across multiple scales, modes and networks of governance (Bulkley and Betsill 2013, Bulkley 2012, Morrison 2007). Often such processes are very chaotic in the complex urban contexts of emerging cities in developing countries (Roy 2009). Therefore, we recommend that the Ramsar framework should encourage the formation of policy networks among agencies of allied policy domains. In addition to forming overt coalitions and networks of like-minded organizations, environmental agencies should also work with influential individuals in rival policy coalitions or decision-making positions to identify and achieve common goals. Such individuals driven by genuine environmental concerns may champion the cause of wetlands in areas and institutions to which environmental agencies lack access (e.g. urban planning, housing, drainage and flood control).

\section{Recognition and enhancement of the existing protective capacities of wetlands}

The protection of cultural values and community use of wetlands are prominent within the current Ramsar framework. However, using those values to enhance the 'protective capacity' of the wetlands is not well articulated. Existing protective capacities (e.g. the synergy of a coherent wetland community, diverse wetland use, and informal institutions in the Kolkata wastewater fishery system) provide latent resistance to the removal or degradation of ecological features in an urbanized landscape (Ernstson 2013). Identifying such protective capacities and strengthening them with formal institutional backing and technical support should be adopted as a key strategy in urban wetlands governance. 
Extension of community participation to community empowerment and environmental justice Although the need for community participation in wetland management is highlighted in the Ramsar framework, a clear strategy is not laid out to achieve true community empowerment. We argue that this deficiency springs from the absence of an 'environmental-justice' perspective in the Ramsar Framework. Access to the benefits of land and wetland ecosystem services is a right of wetland communities that ought to be formally recognized, and denial of that right is a social injustice. Empowerment in this sense means supporting the legal claims and campaigns of these communities (i.e. litigation, petitioning, formation of cooperatives) to overcome that injustice. This will include provision of legal support, logistical support (meeting spaces, secretarial services), and material for value articulation (mapping, scientific studies) for environmental justice campaigns, and representation of these communities at a higher level of decision-making.

\subsection{Beyond Ramsar: Struggles for socio-ecological justice in the emerging cities}

As observed in both Colombo and Kolkata, the rapid conversion of the wetlands to built-up areas has been a result of perverse incentives induced directly or indirectly by government policies. As a result, social segregation has increased and low-income wetland communities have faced forced evictions and loss of ecosystem services. Under such conditions, political struggles (outside the accepted legal framework) inevitably emerge from the disadvantaged communities against the state policies. As observed in other research on environmental justice movements (e.g., Bebbington 2004; Bandyopadhyay 1988), these struggles have taken both non-violent and violent forms. They also may be attached to broader struggles of emancipation along the lines of class, race, caste, or gender (Peet \& Watts 2004). For example, in Colombo, the poor communities living in the wetland fringes formed an openly anti-government action committee to resist evictions and police authority. In Kolkata, in the early 1980s, a forcible community takeover of neglected privately-owned fishponds in the wetlands system helped to protect the community's livelihoods, increased the productivity of the ponds, and maintained the wetland ecological processes. Although undesirable to the ruling establishment, organized political struggle through social mobilization is a vital tool for progressive social change (Conde \& Kallis 2012, Friedmann 1987).

However, successful political struggles will neither organically emerge from the 'bottom' nor will they automatically lead to success. Clear strategies are needed to guide these movements, 
mobilize communities, and learn from success and failures. Although such movements are often loosely organized and sporadic, their success is nevertheless contingent upon strong leadership. As observed in other cases, environmental justice movements have been guided by middle-class intellectuals trained in environmental or social work disciplines, such as the Save the Narmada Movement in India and the Central Andean indigenous movements of Ecuador. These intellectuals can impart their technical and scientific knowledge and introduce advanced social mobilization methods to the struggle, in a manner which complements bottom up leadership. In the struggle for urban wetlands, such progressive intellectuals may emerge from among today's wetland professionals. Although the Ramsar framework cannot overtly support or advocate political struggles within its current institutional boundaries, it has contributed immensely by training a generation of young wetland professionals. Expanding the Convention's conceptual foundations as we have discussed in this article will further strengthen this contribution.

\section{Conclusion}

The Ramsar Convention's contributions have made wetland management an established discipline that is firmly rooted in environmental governance at global and national levels. The Convention has undergone many conceptual transformations in the past 43 years and has extended the scope of the Ramsar framework to concepts such as 'wise use', 'ecosystem services', 'ecosystem values', 'participatory ecosystem management', and 'policy advocacy'. However, notwithstanding the Convention's achievements, the historical factors in the development of the Ramsar framework have also induced certain conceptual drawbacks that weaken its effectiveness in the governance of complex social-ecological systems such as urban wetlands in the emerging cities of developing countries.

By examining the application of the Ramsar framework in urban wetlands governance in two emerging cities, Colombo and Kolkata, we have identified four key weaknesses in the Ramsar framework that have contributed to governance failure in these cases:

- inadequate recognition of the concept of complex social-ecological systems

- inadequate recognition of the full complexity of the policy processes involved in urban governance

- failure to emphasize the difference between community participation and true empowerment at a conceptual level 
- absence of an "environmental justice" perspective

Based on the analysis, we recommend certain pragmatic, strategic and technical modifications to the Ramsar framework that can significantly improve its effectiveness in urban wetlands governance:

- expanding the technical wetland management guidelines to cover the recent scientific advancements in urban ecology, ecosystem complexity and ecological transformation

- emphasizing the importance of mixed land-use planning concepts in emerging cities

- adopting strategies to strengthen policy coalitions and informal social institutions to support sustainable wetland management

- emphasizing community empowerment and advanced multi-level community participation

We also emphasize the importance of wider social struggles for environmental justice (outside formal legal processes) that are occurring in the highly unequal societies of emerging cities. Although the Ramsar framework cannot advocate political struggles within its current institutional confines, environmental justice should be adopted as a key Ramsar principle. The Ramsar framework needs to be supported by further research on the causes and resolution of these concerns which are mounting as more and more developing counties enter the global economy.

Acknowledgements: This research was funded by a CSIRO Integrated Natural Resources Management Research Grant (2011-2014). The School of Geography Planning and Environmental Management, The University of Queensland also provided valuable financial and logistical support. We especially mention the guidance and support provided Dr. Drubhajyoti Ghosh (Kolkata), Prof. Ajith de Alwis (University of Moratuwa, Sri Lanka) and Mrs. Kusum Athukorala (Sri Lanka Water Partnership) while organizing the field work. We also thank the Editor in Chief of Global Environmental Change and the two anonymous reviewers for their valuable comments and guidance. 


\section{References}

Adaman, F., Hakyemez, s., \& Ozkaynak, B. 2009. The political ecology of a Ramsar site conservation failure: the case of Burdur Lake, Turkey. Environment and Planning C, 27: $783-800$

Arnstein, S. R. 1969. A ladder of citizen participation, Journal of American Institute of Planners 35(4): 216-224.

Azarath, J., Banth, P., Azarath, H. \& Selvan, V. 1988. Impact of urbanization on the status of mangrove swamps in Madras. In The Ecology and Management of Wetlands, volume 2: management use and value of wetlands, pp. 225-233, Portland Oregon: Timber Press.

Azous, A. L. \& Horner., R. R. (eds.). 2001. Wetlands and urbanization: Implications for the future. Boca Raton, FL, Lewis Publishers.

Bandyopadhyay, J. \& Shiva V. 1988. Political economy of ecology movements. Economic and Political Weekly, 23(24): 1223-1232.

Barbier, E. B., Acreman M. \& Knowler M. 1997. Economic valuation of wetlands - A guide for policy makers and planners. Gland, Switzerland: Ramsar Convention Bureau.

Bebbington, A. 2004. Movements and modernizations, markets and municipalities: indigenous federations in rural Ecuador. In Liberation Ecologies. pp. 394-421, R. Peet and M. Watts (eds.), London, New York : Routledge.

Bowman, M. 2002. The ramsar convention on wetlands: Has it made a difference? In: Year Book of International Co-Operation on Environment and Development 2002/03, O.S. Stokke (ed.), pp. 61-68, London: Earthscan Publications.

Bulkeley, H. 2012. Governance and the geography of authority: modalities of authorisation and the transnational governing of climate change. Environment and Planning A.;44:2428-2444.

Bulkeley, H. A. \& Betsill, M. M. 2013. Revisiting the urban politics of climate change. Environmental Politics, 22:136-154.

CEA. 1994. Wetland site report and conservation management plan - Colombo Flood Detention Areas. Colombo, Sri Lanka: Central Environmental Authority of Sri Lanka.

Clarke, J. N. \& McCool D. 1985. Staking out the terrain: power differentials among natural resource management agencies. Albany, NY, USA: State University of New York Press. 
Conde, N. M. \& Kallis, G. 2012. The global uranium rush and its Africa frontier, Effects, reactions and social movements in Namibia. Global Environmental Change 22: 596610.

Cutter, S. 1995. Race, class, and environmental justice. Progress in Human Geography 19: 107-118.

Dasgupta, K. 2007. A city divided? planning and urban sprawl in the eastern fringes of Calcutta. In Indian Cities in Transition, A. Shaw (ed.), pp. 314-341. Chennai: Orient Longman.

Ehrenfeld, J. G. 2000. Evaluating wetlands within an urban context. Urban Ecosystems, 4: $69-85$.

Ehrenfeld, J. G. 2004. The expression of multiple functions in urban forested wetlands. Wetlands 24(4): 719-733, doi: 10.1672/0277-5212.

Ernstson, H. 2013. The social production of ecosystem services: A framework for studying environmental justice and ecological complexity in urbanized landscapes. Landscape and Urban Planning 109: 7-17.

Friedmann, J. 1987. Planning in the public domain. Princeton, NJ, U.S.A: Princeton University Press.

Ghosh, D. \& Sen, S. 1987. Ecological history of Calcutta wetland conversion. Environmental Conservation 14 (3): 219-226.

Ghosh, D. 2005. Ecology and traditional wetlands practice, lessons from the wastewater utilization in the East Calcutta Wetlands. Kolkata: Worldview.

Gunasekara, T. 2010. The development war-a 'humanitarian operation' against Colombo's poor. The Sunday Leader 12 May 2010.

Hettiarachchi, M., de Alwis, A., Wijekoon, S. \& Athukorale, K. 2014a. Urban wetlands and disaster resilience of Colombo, Sri Lanka. Interantional Journal of Disaster Resilience in Built Environment 5(1): 79 -90.

Hettiarachchi, M., Athukorala, K., Peiris R. \& de Alwis. A. P. 2012. Recent changes in policy, institutions and ecosystem services in Colombo wetlands. In Ecosystems and Integrated Water Resources Management in South Asia, N. Gunawardane , B. Gopal \& H. Kotagama (eds.), pp. 254-273, New Delhi: Routledge India. 
Hettiarachchi, M., Morrison, T. H., Wickramasinghe, D., Mapa, R., de Alwis, A. P. \& McAlpine, C. 2014b. The environmental history and ecological transformation of the Colombo (Sri Lanka) urban wetlands. Landscape and Urban Planning, 132:55-68.

Hettiarachchi, M., McAlpine, C. and Morrison, T. H. 2013. Governing the urban wetlands: a multiple case-study of policy, institutions and reference points. Environmental Conservation 41:3 doi:10.1017/S0376892913000519

Hobbs, R. J., Higgs, E. and Harris, J. A. 2009. Novel ecosystems: implications for conservation and restoration. Trends in Ecology and Evolution 24(11): 599-605.

Irvin, R., \& Stansbury, J., 2004. Citizen participation in decision making: is it worth the effort? Public Administration Review 64(1): 55-65.

Keen, M., Brown, V. A., \& Dyball, R. 2005. Social Learning: A new approach for environmental management. In Social Learning in Environmental Management, M. Keen, V. A. Brown \& R. Dyball (eds.), pp. 3-22, London: Earthscan.

Keil, R. 2003. Urban political ecology. Urban Geography 24(8): 723-738.

Levin, S. A. 1998. Ecosystems and the biosphere as complex adaptive systems. Ecosystems $1: 431-436$.

Lindblom, C. E., 1959. The science of 'muddling through'. Public Administration Review 19: 79-88.

Mahan, B. L., Polasky, S., and Adams, R. M. 2000. Valuing Urban Wetlands: A Property Price Approach. Land Economics, 76(1): 100-113.

Marcuse, P. \& Kempen, R. V. 2000. Conclusion: a changed spatial order. In: Globalizing Cities: A New Spatial Order? P. Marcuse \& R.V. Kempen (eds.), pp 249-275.Oxford, UK: Blackwell Publications.

Marzluff J. M., Shulenberger, E., Endlicher, W., Alberti M., Bradley, G., Ryan, C., Simon, U. \& ZumBrunnen, C. (eds.) 2008. Urban Ecology. New York: Springer.

Matthews, G. V. T., 1993. The Ramsar Convention on Wetlands: its history and development. Gland Switzerland: Ramsar Convention Bureau.

Morrison, T.H. (2007). Multiscalar governance and regional environmental management. Space and Polity, 11 (3): 227-241. 
Mushacke, F. \& Picard, E. 1999. Vegetated wetlands trends of the New York and lower Hudson River: Final Report. New York: New England Interstate Water Pollution Control Commission.

Nassauer, J. I. 2004. Monitoring the success of metropolitan wetland restorations: cultural sustainability and ecological. Wetlands 24 (4): 756 - 765.

Natori, Y. 1999. Information sheet on Ramsar wetlands: Yatsuhigata. Gland, Switzerland: Ramsar Convention Bureau, <http://www.wetlands.org/reports/ris/2JP007en.pdf> (last accessed 22 April 2014).

Natural Resources Defence Council 1990. The New York environment. Washington, DC, USA: Island Press.

Pahl-Wostl, C. 2009. A conceptual framework for analysing adaptive capacity and multilevel learning processes in resource governance regimes. Global Environmental Change 19(3): 354-365.

Panini, D. 1998. The Ramsar Convention and the national laws and policies for wetlands in India. Gland, Switzerland: Ramsar Convention Secretariat.

Papayannis, T. \& Pritchard, D. E. 2008. Culture and wetlands - a Ramsar guidance document, Gland, Switzerland: Ramsar Convention.

Peet, R. \& Watts, M. 2004. Liberation Ecologies. London: Routledge.

Pickett, S. T. A ., Cadenasso, M. L., Grove, J. M., Nilon, C. H., Pouyat, R. V., Zipperer, W. C. and Constanza, R. 2008. Urban ecological systems: linking terrestrial ecological, physical, and socioeconomic components of metropolitan areas. In Urban Ecology, J. M.Marzluff, E. Shulenberger, W. Endlicher, M. Alberti, G. Bradley, C. Ryan, U. Simon and C. ZumBrunnen (eds.), pp. 99-123, New York: Springer.

Pulido, L. 2000. Rethinking environmental racism: white privilege and urban development in southern California. Annals of the Association of American Geographers 90(1): 12-40.

Robbins, P. 2012. Political ecology. West Sussex, UK: Wiley-Blackwell.

Robinson, L. W. \& Berkes, F. 2011. Multi-level participation for building adaptive capacity: Formal agency-community interactions in northern Kenya. Global Environmental Change 21: 1185-1194. 
Roy, A. 2009. Why India cannot plan its cities: informality, insurgence and the idiom of urbanization. Planning Theory 8:76-87.

Sabatier, P. 1985. Top-down and bottom-up approaches to implementation research: A critical analysis and suggested synthesis. Journal of Public Policy 6(1): 21-48.

Sabatier, P. \& Jenkins-Smith. H. C. 1999. The advocacy coalition framework: An assessment. In Theories of the Policy Process, P. Sabatier (ed.), Boulder, Colo.: Westview Press.

Seto, K. C., Fragkias, M., 2007. Mangrove conversion and aquaculture development in Vietnam:A remote sensing-based approach for evaluating the Ramsar Convention on Wetlands. Global Environmental Change, 17: 486-500

Schmidt, P. and T.H. Morrison (2012) Watershed management in an urban setting: process, scale and administration. Land Use Policy 29: 45- 52.

Smardon, R. C. 2009. Sustaining the worlds wetlands London: Springer.

UN 2008. World urbanization prospects: The 2007 revision. New York: United Nations, Department of Economic and Social Affairs, Population Division.

Urwin, K. \& Jordan, A. 2008. Does public policy support or undermine climate change adaptation? Exploring policy interplay across different scales of governance. Global Environmental Change 18: 180-191.

Water by Design. 2009. Concept design guideline for water sensitive urban design part I, Brisbane: South East Queensland Healthy Waterways Partnership.

Xu, K., Kong, C., C, W., Liu, G., Deng, H. \& Zhang, Y. 2009. Dynamic changes in Tanxgunhu wetlands over a period of rapid development (1953-2005) in Wuhan, China. Wetlands 29: 1255-1261.

Yokohari, M., Brown, R. D. \& Takeuchi, K. 1994. A framework for the conservation of rural ecological landscapes in urban fringe area in Japan. Landscape and Urban Planning 26: $757-762$.

Yokohari, M., Takeuchi, K., Watanabe ,T. \& Yokata, S. 2008. Beyond greenbelts and zoning: A new planning concept for the environment of Asian mega-cities. In Urban Ecology, J. M. Marzluff, E. Shulenberger, W. Endlicher, M. Alberti, G. Bradley, C. Ryan, U. Simon \& C. ZumBrunnen (eds.), pp. 783-797, New York: Springer. 
Zimmerer, K. S. 2000. The reworking of conservation geographies: non-equilibrium landscapes and nature-society hybrids, Annals of the Association of American Geographers 90 (2): $356-69$. 